\title{
Nutritional and Sensory Quality of Kocho Mixed with Whole Soybean and Okara
}

\author{
Tegene Atlaw ${ }^{1}$, Misgana Banti ${ }^{1, ~ *}$, Wabi Bajo ${ }^{2}$, Bilatu Agza ${ }^{3}$, Tamene Haile ${ }^{1}$ \\ ${ }^{1}$ Food Science and Nutrition Research, Jimma Agricultural Research Center, Ethiopian Institute of Agricultural Research, Jimma, Ethiopia \\ ${ }^{2}$ Food Science and Nutrition Research, Melkasa Agricultural Research Center, Ethiopian Institute of Agricultural Research, Adama, Ethiopia \\ ${ }^{3}$ Food Science and Nutrition Research, Ethiopian Institute of Agricultural Research, Addis Ababa, Ethiopia
}

Email address:

misganabanti2013@gmail.com (M. Banti)

*Corresponding author

\section{To cite this article:}

Tegene Atlaw, Misgana Banti, Wabi Bajo, Bilatu Agza, Tamene Haile. Nutritional and Sensory Quality of Kocho Mixed with Whole Soybean and Okara. International Journal of Nutrition and Food Sciences. Vol. 9, No. 6, 2020, pp. 150-153. doi: 10.11648/j.ijnfs.20200906.12

Received: August 30, 2020; Accepted: September 17, 2020; Published: November 27, 2020

\begin{abstract}
Kocho (flat bread) is one of the food products made from enset, a staple food consumed by about $20 \%$ of the Ethiopian population. It is good sources of minerals, vitamins and carbohydrate, but low in protein and fat contents. Formulation of kocho with protein and fat rich sources like soybean can makes it nutrient dense food. Thus, the study was aimed to formulate kocho with soybean flour and okara, and evaluate its nutritional value and sensory acceptance. Kocho was mixed with whole soybean and okara flours in seven different proportions. Five point hedonic scales and AOAC methods were used to evaluate the sensory quality and proximate analysis of kocho samples respectively. Sensory evaluation results showed that all the formulations were in the acceptable range. Moisture, ash, fat, protein, fiber and carbohydrate contents of kocho was in the range of 6.81-9.41, 2.85-5.50, 3.87-10.08, 3.32-14.82, 1.61-2.98 and 60.36-78.29\%, respectively. The addition of both whole soybean and okara significantly increased the protein and fat contents. Therefore, it is possible to improve nutritional quality of kocho by partially substituting with soybean flour and okara without considerable effect on consumer acceptance of the product. The substitution level evaluated in the current study was only up to $25 \%$ and further study is required to investigate the impact of more substitution levels.
\end{abstract}

Keywords: Soybean, Okara, Kocho, Proximate Composition, Sensory Quality

\section{Introduction}

The problem of food and nutrition security remains the main health and development issue in our country, Ethiopia. With $38 \%$ of children less than five years stunted, $10 \%$ wasted and $21 \%$ of the total population undernourished, the country has one of the highest levels of chronic under nutrition in the world [1]. Due to the high cost of protein rich foods like animal protein, the low income and rural society are hardly able to get access to adequate protein. Food formulations technologies help enrich the food with low protein content with protein-rich foods to solve problems of malnutrition.

Enset (Ensete ventricosum) is the basis for the staple food consumed by about $20 \%$ of the Ethiopian population [2]. It is relatively tolerant against drought, heavy rains and flooding, and the crop has the potential to ensure nourishment of the Ethiopian population even at extreme weather conditions. Though enset can be grown in many regions of Ethiopia, mostly the inhabitants of the central and southwestern parts only are growing and using enset as a staple and co-staple crop. Owing to its multi-purpose application and its robustness, there is a potential to expand its production to other regions of Ethiopia and other African countries [2-4]. Kocho is one of the food products generated from enset by spontaneous fermentation of decorticated and pulverized pseudo-stem and corm sections [2]. It is the bulk of the fermented starch obtained from the mixture of the decorticated (scraped) leaf sheaths and the grated corm [5]. and prepared by fermenting the product; baked as a thin bread. Kocho is a good source of carbohydrate, $\mathrm{Ca}$ and $\mathrm{Fe}$ [6], but is low in protein and fat.

On the other hand, legumes are most important sources of 
food supply in terms of food energy as well as nutrients including protein and fats. Soybean (Glycine $\max \mathrm{L})$ is a legume widely grown for its edible bean which has high nutritional value, long storage times and relatively low cost in comparison to animal products. It is becoming popular in the country; and contains $40 \%$ good quality protein, $20 \%$ fat, $23 \%$ of carbohydrate and a reasonable amount of minerals and vitamins and is excellent healthy food [7]. In addition to enhancing protein and fat levels, soybean addition believe to improve the organoleptic profile of kocho based foods such as crust color, crumb body, resilience, toasting characteristics and shelf life due to the presences of essential fatty acids and amino acids $[8,9]$. Thus, the study was aimed to formulate kocho with soybean flour and okara, and evaluated its nutritional value and sensory acceptance.

\section{Materials and Methods}

\subsection{Sample Collection and Preparation}

\subsubsection{Kocho and Soybean Flour}

The squeezed out and ready kocho was bought from Jimma market and pulverized into flour and then sieved as indicated in literature [10]. Powder of fermented Kocho is popular in market for baking (bread, injera), and porridge. One Soybean varieties (Clark $30 \mathrm{Kg}$ ) were collected from the soybean breeding research program of Jimma Agricultural Research Center and cleaned, roasted, hulls removed and milled using grain miller (FW 100 High-Speed Universal Disintegrator) to obtain soybean flour as per the procedures in literature [11].

\subsubsection{Okara Preparation}

The cleaned soybean seeds were boiled in water for 10 minutes followed by discarding the hot water, soaked at ambient temperature for 12 hours, washed, and hulls removed. Then, rinsed with water and blended using juice machine (GSB-1514) and cooked at $100^{\circ} \mathrm{C}$ for 20 minutes. The remaining residue (Okara) after filtering the soymilk using cheesecloth was collected, dried and milled again as flour for blending following the proposed procedure in literature [12].

\subsubsection{Formulation of Blends}

Flours of kocho, whole soybean and okara were mixed as in table 1.

Table 1. Formulations of kocho with soybean flour and okara.

\begin{tabular}{llll}
\hline \multirow{2}{*}{ Treatments } & \multicolumn{3}{l}{ Formulation proportions } \\
\cline { 2 - 4 } & Kocho-soybean flour & Treatments & Kocho-Okara \\
\hline 1 & $85: 15$ & 4 & $85: 15$ \\
2 & $80: 20$ & 5 & $80: 20$ \\
3 & $75: 25$ & 6 & $75: 25$ \\
& & 7 (Control) & $100 \%$ Kocho \\
\hline
\end{tabular}

\subsubsection{Kocho (Flat Bread) Preparation Procedure}

Kocho was prepared in a normal kocho preparation procedures. The blended flour was initially mixed well, water was added, and then, followed by kneading and baking on a flat griddle (Metad) by wrapping with enset leaf to obtain flat bread (kocho). The kocho was drawn from the griddle and presented for sensory evaluation after cooling to ambient temperature for $1 \mathrm{hr}$. Kocho samples were dried for $24 \mathrm{~h}$ at $65^{\circ} \mathrm{C}$ in an oven and ground for proximate analysis.

\subsection{Sensory Analysis}

A semi-trained panel (a panel briefed about the scoring of sensory attribute) of 35 people, who were consuming kocho, evaluated in duplication by using a five-point hedonic scale ( $1=$ dislike very much, $5=$ like very much). The attributes evaluated were texture, taste, color and overall acceptability were studied following method indicated in literature [13].

\subsection{Proximate Analysis}

Crude protein, crude fat, crude fiber, moisture and ash contents of kocho samples were determined following standard method [14]. Total carbohydrate was calculated by difference: 100 - (\% Moisture $+\%$ Crude protein $+\%$ Crude fat $+\%$ Crude fiber $+\%$ Ash) [15]. Energy value per $100 \mathrm{~g}$ was calculated using the Atwater conversion factors, where $\mathrm{E}$ (kcal per $100 \mathrm{~g}$ ) [9 X crude fat $(\%)+4 \mathrm{x}$ crude proteins $(\%)$ $+4 \mathrm{x}$ total carbohydrates $(\%)][16]$.

\subsection{Statistical Analysis}

The data were subjected to ANOVA by using SAS software version 9.3. Separation of the mean values was carried out using least significant difference (LSD) test at $\mathrm{p}<$ 0.05 .

\section{Results and Discussions}

\subsection{Proximate Compositions and Contents of Okara, Soybean Flour and Kocho}

The proximate composition and energy content of the ingredient used in formulation were given in table 2 below. The average moisture content of okara, soybean flour and kocho are indicated in the table to range from 6.29 for soybean flour to $9.26 \%$ for okara. The average protein content revealed for okara, soymilk byproduct by this study was $39.59 \%$ which was slightly higher than the report $(31.7 \%)$ by [17]. Slightly higher protein content reported here might be attributed to difference in variety and growth condition of the soybean. Likewise, average fat content of okara reported by this research $26.14 \%$ is also slightly higher than the value $(14.7 \%)$ fat reported in previous study [17] which may again be attributed to difference in variety and growth condition of the soybean.

The flour of soybean variety used in this study contains about $42.82 \%$ protein. This value is in appreciable agreement with previously reported $46.06 \%$ protein content of soybean flour in a literature [18]. Such high protein content of soybean flour and product makes it preferable source of protein for fortification low protein food like kocho of this study. Similarly, average fat content of $27.90 \%$ for soybean 
flour was reported in this study. This value is also in line with the previous fat content reported for soybean flour $(20.03 \%)$ by [18]. Being appreciable fat source is also an advantage of soybean to be considered for different food product fortification.

Table 2. Proximate compositions and contents of okara, soybean and kocho flour.

\begin{tabular}{llll}
\hline Parameters & Okara & Soybean flour & Kocho \\
\hline Moisture & 8.10 & 6.29 & 9.16 \\
Protein & 39.59 & 42.82 & 3.32 \\
Crude fat & 26.14 & 27.90 & 0.38 \\
Crude fiber & 4.76 & 2.77 & 2.58 \\
Ash & 4.55 & 5.01 & 2.85 \\
Carbohydrate & 16.86 & 15.01 & 78.29 \\
Energy & 461.05 & 483.22 & 362.36 \\
\hline
\end{tabular}

According to the finding of this study, the average protein and fat contents of kocho flour is as low as 3.32 and $0.38 \%$ respectively. The protein content reported in this study is therefore in line with range of protein content $(3.47-4.07 \%)$ reported in literature [19]. Similarly, average fat content of kocho $(0.38 \%)$ reported in this study is in agreement with the result reported $(0.42-0.53 \%$ fat) by [19]. It is based on this base line that fortification of kocho with high protein and fat source legumes like soybean was implemented.

The average fiber, ash, carbohydrate and energy contents reported in this study for all the ingredients are also indicated in the table 2 above. These reported values are also appreciable in soybean based products except carbohydrate content.

\subsection{Sensory Evaluation}

The sensory result of kocho fortified with soybean flour and okara flour is presented in Table 3. The sensory evaluation ranged from 3.30 to 4.28 for appearance, 3.55 to 4.12 flavors, 3.46 to 4.16 mouth feel and 3.47 to 4.17 for overall acceptability. According to the result of sensory evaluation, the kocho fortified with okara and soybean flour is generally acceptable scoring higher than three sensory score in all sensory parameters. The appearance of the kocho was found to be slightly better when partially substituted with okara. The difference in sensory score given for flavor, mouth feel and overall acceptability are statistically non significant for all proportions evaluated in this research. The sensory evaluation result indicated that kocho fortified with both soybean flour and okara were in acceptable range in all parameters up $25 \%$.

Table 3. Sensory results of soybean fortified kocho.

\begin{tabular}{lllll}
\hline Treatment & Appearance & Flavor & Mouthfeel & $\begin{array}{l}\text { Overall } \\
\text { acceptability }\end{array}$ \\
\hline 2 & $3.30^{\mathrm{b}}$ & $3.59^{\mathrm{ab}}$ & $3.46^{\mathrm{a}}$ & $3.54^{\mathrm{a}}$ \\
1 & $3.42^{\mathrm{b}}$ & $3.62^{\mathrm{ab}}$ & $3.58^{\mathrm{a}}$ & $3.47^{\mathrm{a}}$ \\
3 & $3.44^{\mathrm{b}}$ & $3.55^{\mathrm{a}}$ & $3.59^{\mathrm{a}}$ & $3.67^{\mathrm{a}}$ \\
4 & $3.75^{\mathrm{ab}}$ & $3.74^{\mathrm{ab}}$ & $3.91^{\mathrm{a}}$ & $3.79^{\mathrm{a}}$ \\
5 & $3.83^{\mathrm{ab}}$ & $3.99^{\mathrm{ab}}$ & $3.91^{\mathrm{a}}$ & $4.03^{\mathrm{a}}$ \\
6 & $3.62^{\mathrm{ab}}$ & $3.74^{\mathrm{ab}}$ & $3.87^{\mathrm{a}}$ & $3.74^{\mathrm{a}}$ \\
7 & $4.28^{\mathrm{a}}$ & $4.12^{\mathrm{a}}$ & $4.16^{\mathrm{a}}$ & $4.17^{\mathrm{a}}$ \\
Mean & 3.66 & 3.76 & 3.78 & 3.77 \\
CV $(\%)$ & 9.15 & 5.94 & 8.72 & 7.91 \\
\hline
\end{tabular}

Means with the same letter in a column are not significantly different ( $\mathrm{p}>0.05$ ) $\mathrm{T}_{1}=80 \%$ kocho\& $20 \%$ soy flour, $\mathrm{T}_{2}=85 \%$ kocho $\& 15 \%$ soy flour, $\mathrm{T}_{3}=75 \%$ kocho\& $25 \%$ soy flour, $\mathrm{T}_{4}=80 \%$ kocho\& $20 \%$ okara, $\mathrm{T}_{5}=85 \%$ kocho $\& 15 \%$ okara, $\mathrm{T}_{6}=75 \%$ kocho $\& 25 \%$ okara, $\mathrm{T}_{7}=100 \%$ kocho

\subsection{Proximate Analysis}

Proximate results of whole soybean and okara fortified kocho are presented in Table 3. Moisture content of the blend kocho were ranged from $6.81 \%$ to $9.41 \%$, crude fat from $3.87 \%$ to $10.08 \%$, protein from $3.32 \%$ to $14.82 \%$, crude fiber from $1.61 \%$ to $2.98 \%$, Ash from $2.85 \%$ to $5.50 \%$ carbohydrate from $60.36 \%$ to $78.29 \%$, and energy ( $k$ cal) from 362.36 to 389.84 . Crude fat and protein contents were increased significantly $(\mathrm{p}<0.05)$ as incorporation of soybean flour and okara increased. The fat content of control kocho was $3.81 \%$ and was increased to $10.08 \%$ fat for $80 \%$ kocho with $20 \%$ soybean flour. Similarly, the protein content also was increased from $3.32 \%$ for control to $14.82 \%$ protein content for $20 \%$ soybean flour substitution. In similar manner, partial substitution kocho with okara can also improve the protein and fat content of kocho. Though it was not in a proportional way, addition of both soybean flour and okara significantly increased the ash content of kocho. The carbohydrate content of kocho-okara formulation, in general, was higher than those of kocho-soybean flour formulations (Table 3). Composition analysis of Kocho indicated that kocho has high carbohydrate and low protein content [6].

Table 4. Composition analysis of soybean and okara flour fortified kocho.

\begin{tabular}{|c|c|c|c|c|c|c|c|}
\hline Treatment & Moisture & Protein & Crude fat & Crude fiber & Ash & Carbohydrate & Energy \\
\hline 1 & $7.60^{\text {cd }}$ & $10.63^{b}$ & $10.08^{\mathrm{a}}$ & $2.42^{\text {abc }}$ & $4.58^{\mathrm{ab}}$ & $64.68^{\text {cd }}$ & $386.98^{\mathrm{ab}}$ \\
\hline 2 & $6.81^{\mathrm{d}}$ & $14.82^{\mathrm{a}}$ & $9.53^{\mathrm{a}}$ & $2.98^{\mathrm{a}}$ & $5.5^{\mathrm{a}}$ & $60.36^{d}$ & $386.51^{\mathrm{ab}}$ \\
\hline 3 & $8.55^{\mathrm{ab}}$ & $10.62^{\mathrm{b}}$ & $9.517^{\mathrm{a}}$ & $2.14^{\mathrm{bc}}$ & $4.50^{\mathrm{ab}}$ & $64.68^{\mathrm{cd}}$ & $386.85^{\mathrm{ab}}$ \\
\hline 4 & $9.41^{\mathrm{a}}$ & $6.92^{\text {bcd }}$ & $7.29^{\mathrm{ab}}$ & $1.94^{\mathrm{bc}}$ & $3.04^{\mathrm{bc}}$ & $71.40^{\mathrm{b}}$ & $372.22^{\mathrm{ab}}$ \\
\hline 5 & $7.82^{\mathrm{bc}}$ & $5.13^{\mathrm{cd}}$ & $7.85^{\mathrm{a}}$ & $2.29^{\mathrm{abc}}$ & $3.93^{\mathrm{abc}}$ & $72.99^{\mathrm{ab}}$ & $376.46^{\mathrm{ab}}$ \\
\hline 6 & $8.52^{\mathrm{ab}}$ & $7.63^{\mathrm{bc}}$ & $9.53^{\mathrm{a}}$ & $1.64^{\mathrm{c}}$ & $3.05^{\mathrm{bc}}$ & $69.63^{b c}$ & $389.84^{\mathrm{a}}$ \\
\hline 7 & $9.16^{\mathrm{a}}$ & $3.32^{\mathrm{d}}$ & $3.81^{\mathrm{b}}$ & $2.58^{\mathrm{ab}}$ & $2.85^{\mathrm{c}}$ & $78.29^{\mathrm{a}}$ & $362.36^{\mathrm{b}}$ \\
\hline CV $(\%)$ & 6.37 & 26.78 & 25.81 & 20.27 & 23.36 & 4.47 & 4.01 \\
\hline
\end{tabular}

Means with the same letter in a column are not significantly different $(\mathrm{p}>0.05)$.) $\mathrm{T}_{1}=80 \%$ kocho \& $20 \%$ soy flour, $\mathrm{T}_{2}=85 \%$ kocho\& $15 \%$ soy flour, $\mathrm{T}_{3}=75 \%$ kocho $25 \%$ soy flour, $\mathrm{T}_{4}=80 \%$ kocho $\& 20 \%$ okra, $\mathrm{T}_{5}=85 \%$ kocho $\& 15 \%$ okra, $\mathrm{T}_{6}=75 \%$ kocho $\& 25 \%$ okra, $\mathrm{T}_{7}=100 \%$ kocho. 


\section{Conclusion and Recommendation}

The study has demonstrated that addition of both whole soybean and its byproduct okara can enhance protein and fat contents of kocho with acceptable sensory quality. This in turn shows that the product can enhance household food and nutrition security for the growing population of Ethiopia where protein-energy malnutrition affects a greater part of the country. The substitution level evaluated in the current study was only up to $25 \%$. Further study however is required to investigate the impact of substitution of soybean and okara flour to higher levels.

Therefore, it is very important to considerer the use of soybean and byproduct (okara) while preparing kocho from enset both at household and different restaurants at inclusion level as high as $25 \%$ on the basis of this research report. This however is possible if the extension and demonstration activities performed to the required level and thus the extension and demonstration work will be the next part of this work by Jimma Agricultural Research Center of Ethiopian Institute of Agricultural Research. Furthermore, the work related to the industrialization of such tradition products in our country Ethiopia is less or not addressed so far and needs more and more research attentions in the future.

\section{References}

[1] FAO (2018). Food and Agriculture Organization of the United Nations. The State of Food Security and Nutrition in the World. Building Climate Resilience for Food Security and Nutrition, Rome, 2018.

[2] Birmeta G., Nybom H., and Bekele E. 2004. Distinction between wild and cultivated enset (Ensete ventricosum) gene pools in Ethiopia using RAPD markers. Hereditas 140: 139148. https://doi.org/10.1111/j.1601-5223.2004.01792.x.

[3] Birmeta G., Nybom H., and Bekele E. 2002. RAPD analysis of genetic diversity among clones of the Ethiopian crop plant Ensete ventricosum. Euphytica 124: 315-325. https://doi. org/10.1023/a:1015733723349.

[4] Daba T. and Shigeta M. (2016) Enset (Ensete ventricosum) production in Ethiopia: its nutritional and socio-cultural values. Agric Food Sci Res 3: 66-74.

[5] Kalekristos Y., 2010. Influence of baking time and temperature on the quality of kocho biscuit enriched with Faba Bean and wheat. Addis Ababa University, Addis Ababa.

[6] Atlabachew, M. and Chandravanshi, B. S., 2008. Levels of major, minor and trace elements in commercially available enset (Ensete ventricosum (Welw.), Cheesman) food products
(Kocho and Bulla) in Ethiopia. Journal of Food Composition and Analysis, 21 (7), 545-552.

[7] Slavin and Koecher, 2014. Soyfoods guide. Solid Research Foundation Behind Dietary Guidelines, MyPlate Recommendations

[8] Nilufer, D., Boyacioglu, D. \&Vodovotz, Y. 2008. The functionality of soymilk powder and its components in fresh soy bread. Journal of Food Science, 73 (4), 275-281.

[9] Dhingra, S. \& Jood, S. 2002. Physico-chemical and nutritional properties of cereal-pulse blends for bread making. Journal of Nutritional Health, 16 (3), 183-194.

[10] Asres A., and Omprakash S., 2014. Extension of Enset Plant Product for Rural Development in Ethiopia. Journal of Agricultural Economics, Extension and Rural Development 2 (3): 031-040.

[11] Nwakalor, C. N. and Obi, C. D., 2014. Formulation and sensory evaluation of sorghum based weaning food fortified with soybean and unripe plantain flour International. Journal of Nutrition and Food Sciences; 3 (5): 387-390.

[12] Alpaslan M., and Hayta M., 2002. Hydration properties, soymilk and okara yield of soybean affected by agronomic factors. Nahrung 46: 141-143.

[13] Kolapo, A., and Oladimeji, G., 2008. Production and quality evaluation of Soy-corn milk. Journal of Applied Biosciences, 1 (5902), 40-45.

[14] AOAC, 2016. Official Methods of Analysis of the Association of Official Analytical Chemists, 20th edn. Washington, DC: AOAC International.

[15] Onwuka G. I., 2005. Food analysis and instrumentation theory and practice (Napthali prints. Lagos. 2005).

[16] Polycarp, D., Afoakwa, E. O., Budu, A. S., Otoo, E., 2012. Characterization of chemical composition and anti-nutritional factors in seven species within the Ghanaian yam (Dioscorea) germplasm. Int. Food Res. J. 19 (3), 985-992.

[17] Katayama M. and Wilson L. A., 2008. Utilization of Okara, a Byproduct from Soymilk Production, through the Development of Soy-Based Snack Food. Journal of food science 73: 153-157.

[18] Redondo-Cuenca A. M., Jose' Villanueva S., Inmaculada M., 2007. Soybean seeds and its by-product okara as sources of dietary fibre. Measurement by AOAC and Englyst methods. Food Chemistry 108 (2008) 1099-1105.

[19] Kelbessa U. Alemu F. and Eskinder B., 2017. Natural fermentation of Enset (Ensete ventricosum) for the production of Kocho. Ethiopian Journal of Health Development; 11 (1): $75-81$ 